\title{
Gene characterization of Bradyrhizobium spp. strains contrasting in biological nitrogen fixation efficiency in soybean
}

\author{
Caracterização dos genes de cepas de Bradyrhizobium spp. \\ contrastantes quanto à eficiência de fixação biológica de nitrogênio \\ em soja
}

\author{
Camila de Medeiros ${ }^{1}$; Gilberto Aguiar Pereira ${ }^{2}$; Janyeli Dorini Silva de Freitas ${ }^{1}$; \\ Olavo Bilac Quaresma de Oliveira Filho' ${ }^{1}$; Juliana Silveira do Valle ${ }^{3}$; \\ Giani Andrea Linde ${ }^{3}$; Luzia Doretto Paccola-Meirelles ${ }^{3 *}$; Nelson Barros Colauto ${ }^{3}$; \\ Fernando Gomes Barcellos ${ }^{4}$
}

\begin{abstract}
Highlights:
Gene characterization contributes in the soybean BNF process understanding.

Four genes were characterized in B. japonicum strains contrasting in BNF efficiency.

Only blr3208 and blr4511 genes amplified for most of the strains.

blr3208 and blr4511 genes showed highly preserved internal regions among strains.

This preservation may be related to bacterial adaptation during evolution.
\end{abstract}

\begin{abstract}
Bacteria from genus Bradyrhizobium can establish symbiosis with soybean and supply the plant nitrogen demands via biological nitrogen fixation (BNF). This study aimed to characterize genes related to BNF efficiency in B. japonicum strains contrasting in BNF efficiency. These gene sequences were previously identified in B. japonicum (strain S370) as probably related to the BNF efficiency in soybean using a DNA subtractive technique. These genes were amplified with primers based on B. japonicum USDA110 genome. The PCR products were digested with restriction endonucleases and the RFLP products were analyzed by horizontal electrophoresis. Among the four genes, only blr3208 and blr4511 amplified for most of the strains. Neither polymorphism of the restriction profile of blr3208 and blr 4511 genes nor with endonuclease for PCR-RFLP was observed. The contrasting strains had blr3208 and blr4511 genes sequenced and the multiple alignment analysis of nucleotide sequences showed the presence of preserved internal regions, confirming the analysis with PCR-RFLP. The blr3208 and blr4511 genes are highly conserved among $B$. japonicum strains, which may be related to adaptive function during the evolutionary process of Bradyrhizobium genus.
\end{abstract}

Key words: Bradyrhizobium. Rhizobacteria. PCR-RFLP. Restriction Polymorphisms.

\footnotetext{
1 Discentes do Programa de Pós-graduação em Biotecnologia Aplicada à Agricultura, Laboratório de Biologia Molecular, Universidade Paranaense, UNIPAR, Umuarama, PR, Brasil. E-mail: camilamedeiros_biologa@hotmail.com; janyeliquimica@ hotmail.com; olavo.filho@edu.unipar.br

2 Discente do Curso de Doutorado do Programa de Pós-Graduação em Genética e Biologia Molecular, Departamento de Biologia Geral, Universidade Estadual de Londrina, UEL, Londrina, PR, Brasil. E-mail: gilbertopperera@gmail.com

3 Profs. Drs., Programa de Pós-Graduação em Biotecnologia Aplicada à Agricultura, Laboratório de Biologia Molecular, UNIPAR, Umuarama, PR, Brasil. E-mail: jsvalle@prof.unipar.br; gianilinde@prof.unipar.br; luziadoretto@prof.unipar.br; nbc@prof. unipar.br

4 Prof. Dr., Programa de Pós-graduação em Genética e Biologia Molecular, Departamento de Biologia Geral, UEL, Londrina, PR, Brasil. E-mail: fernando.barcellos@uel.br

* Author for correspondence
} 


\begin{abstract}
Bactérias do gênero Bradyrhizobium podem estabelecer simbiose com a soja e suprir a demanda de nitrogênio pela fixação biológica de nitrogênio (FBN). Este estudo teve como objetivo caracterizar genes relacionados à eficiência na $\mathrm{FBN}$ em cepas de $B$. japonicum contrastantes quanto a eficiência na FBN. As sequências gênicas relacionadas à eficiência da FBN em soja foram previamente identificadas na cepa S370 de B. japonicum utilizando uma técnica de DNA subtrativo. Os genes foram amplificados com iniciadores construídos a partir do genoma da cepa USDA 110. Os produtos de PCR foram digeridos com endonucleases de restrição e os produtos de RFLP foram analisados por eletroforese horizontal. Dos quatro genes estudados, apenas blr 3208 e blr 4511 amplificaram na maioria das cepas. Não foi observado polimorfismo no perfil de restrição dos genes blr 3208 e blr 4511 por PCR-RFLP. As cepas contrastantes tiveram os genes blr 3208 e blr 4511 sequenciados e a comparação das sequências nucleotídicas por análise de alinhamento múltiplo mostrou a presença de regiões internas preservadas, confirmando a análise realizada por PCR-RFLP. Os genes blr 3208 e blr 4511 são altamente conservados entre as cepas de $B$. japonicum, o que pode estar relacionado à função adaptativa durante o processo evolutivo do gênero Bradyrhizobium.
\end{abstract}

Palavras-chave: Bradyrhizobium. Rizobactérias. PCR-RFLP. Polimorfismo de restrição.

\section{Introduction}

Diazotrophic bacteria, collectively known as rhizobia, have been contributing to intensify soybean (Glycine max L.) productivity by using atmospheric nitrogen $\left(\mathrm{N}_{2}\right)$. In this process, known as biological nitrogen fixation (BNF), the bacteria fixes the molecular nitrogen that is transferred to the plant as the main nitrogen source. On the other hand, the plant provides photoassimilates necessary for the bacterial development (Göttfert, 1993). BNF based on more responsive bacterial strains enabled soybean to be cultivated in Brazil without using mineral nitrogen and resulted in the decrease of production costs (Bortolan, Barcellos, Marcelino, \& Hungria, 2009). The high protein content in soybean grains demands a large amount of nitrogen by the crop. According to Hungria, Campo and Mendes (2007), for a productivity of $3000 \mathrm{~kg} \mathrm{ha}^{-1}$ of soybean grains, $240 \mathrm{~kg}$ of nitrogen are necessary. The provision of nitrogen fertilizer to the plant has a high economical cost and part of the nitrogen is lost by leaching and volatilization (Silva, Freitas, \& Stamford, 2002), leading to environmental costs. However, the nitrogen demand of Brazilian soybean can be mainly supplied by BNF, dismissing nitrogen fertilization and making the production process economically and ecologically sustainable (Santos, Nicolás, \& Hungria, 2006; Hungria \& Mendes, 2015).

The main bacteria capable of acting symbiotically for soybean BNF are Bradyrhizobium japonicum Kirchner, 1896 (Jordan, 1982), also reclassified as Bradyrhizobium diazoefficiens sp. nov. (Delamuta et al., 2013), and Bradyrhizobium elkanii Kuykendall et al., 1993 (Orrell \& Nicolson, 2020). The symbiosis between Bradyrhizobium spp. and soybean is a complex process that involves the expression of specific genes of the plant and bacterium (Hungria \& Stacey, 1997; Wei et al., 2008; Passaglia, 2017) and an exchange of highly coordinated signals between them (Spaink, 2000). Soybean plants secrete the flavonoids genistein and daidzein in the rhizosphere, which are recognized by the bacteria as a signal for the induction of nodulation genes (nod) that trigger the production of lipo-chitooligosaccharides (LCO's), known as Nod factors (Liu \& Murray, 2016). These signals from the bacteria to the plant start the symbiosis and guide the bacteria to the plant root cortex (Kijne, 1992; Sharma et al., 2020). Next, the plant cells begin a cell division process stimulated by the Nod factor, resulting in a characteristic structure, 
the nodule (Caetano-Anollés \& Gresshoff, 1991, Bortolan et al., 2009). The formation of root nodules leads to $\mathrm{N}_{2}$ fixation and assimilation by the plant (Reis, Mendes, Reis, \& Hungria, 2011). Two other groups of genes named nif and fix are involved in the BNF process, specifically in the synthesis of the nitrogenase complex and the electron transport chain, respectively (Hungria \& Stacey, 1997; Shamseldin, 2013).

Several studies have been trying to understand the BNF process and identify genes related to rhizobia-legume symbiosis (Barcellos, Batista, Menna, \& Hungria, 2009; Wang, Liu, \& Zhu, 2018). The nodulation genes (nod) and nitrogen-fixation genes (nif) are the main drivers of the interaction between rhizobia and host plants (Kaminski, Batut, \& Boistard, 1998; Van Hameren, Hayashi, Gresshoff, \& Ferguson, 2013). However, other genes also affect the efficiency of nodulation and nitrogen fixation (Mahmud, Makaju, Ibrahim, \& Missaoui, 2020). Godoy et al. (2008) reported the partial genome sequencing of B. japonicum (strain CPAC15), and identified potential genes related to BNF efficiency and competitiveness.

Barcellos et al. (2009), based on a technique of representational difference analysis (RDA), described by Lisitsyn, Lisitsyn and Wigler (1993), compared two B. japonicum strains (S370 and S516) contrasting in their BNF efficiency with soybean. The "tester" strain S370 presented higher capacity (three times more fixed $\mathrm{N}_{2}$ ) and efficiency (twice as more $\mathrm{N}_{2}$ fixed per gram of nodule) of $\mathrm{N}_{2}$ fixation than the "driver" strain S516. Barcellos et al. (2009) demonstrated the presence of genes related to BNF efficiency only for the strain S370 and identified considerable polymorphism for these genes. On the functional category of transport and binding proteins, six genes were identified such as two putative $\mathrm{ABC}$ transporter substrate-binding proteins (blr4511 and bll7921 genes), a putative ABC-transporter ATP-binding protein (bll5893 gene), L-amino-acid ABC-transporter ATP-binding protein (aapP gene), maltose-malt-dextrin import
ATP-binding protein (malK gene), and a multiple sugar-binding periplasmic receptor ChvE precursor (blr3208 gene). The malk and aapP genes were previously studied (Batista \& Hungria, 2012; Perin et al., 2018). Therefore, in our study we analyzed the genes related to the functional category of transport and binding proteins, as this gene category codes for important membrane transporters in the molecule transport involved in the exchange of signals between bacteria (rhizobia) and leguminous plants (Barcellos et al., 2009). Thus, this study aimed to characterize the blr4511, bll7921, bll5893 and blr3208 genes in B. japonicum strains contrasting in BNF efficiency to improve the knowledge on bacterial biodiversity of agroindustrial interest.

\section{Materials and Methods}

\section{Biological material}

Bradyrhizobium spp. strains from the culture collection of the Brazilian Microbial Resource Center (http://www.bmrc.lncc.br/) at Embrapa Soja were utilized. Fortheen contrasting strains for BNF effectiveness in soybean were studied and coded as CPAC7, S204, S340, S370, S372, S406, S452, S468, S478, S490, S516, SEMIA586, USDA110, and USDA6 (Hungria, Boddey, Santos, \& Vargas, 1998; Santos, Vargas, \& Hungria, 1999). These strains were also cultivated in culture medium yeast mannitol agar (YMA) or yeast mannitol broth (YMB) as described by Vincent (1970), in the dark, at $28{ }^{\circ} \mathrm{C}$, and then preserved at $-70{ }^{\circ} \mathrm{C}$ in added $30 \%$ glycerol, for a long term, or at $4^{\circ} \mathrm{C}$ in YMB or YMA for continuous use (Ribeiro, Barcellos, Thompson, \& Hungria, 2009).

\section{DNA extraction and oligonucleotide synthesis}

The DNA of each strain was extracted, quantified and diluted in ultrapure water at $5 \mathrm{ng} \mu \mathrm{L}^{-1}$ according to protocol described by Barcellos et al. (2009). The genes listed in Table 1, previously identified by Barcellos et al. (2009) as potentially related to 
the BNF efficiency in soybean, were selected for PCR amplification of each strain. The primers were built based on the genome of B. japonicum strain USDA110 (NCBI; http://www.ncbi.nlm.nih.gov/ nuccore/27375111) whose genome was completely sequenced by Kaneko et al. (2002). The FastPCR software (Kalendar, Lee, \& Schulman, 2009) was used for building the primers according to the manufacturer's parameters and recommendations.

Table 1

Bradyrhizobium japonicum (USDA 110) genome-based oligonucleotide primers (forward and reverse) and expected size of amplified fragments

\begin{tabular}{|c|c|c|c|c|c|}
\hline Function & Gene & $\begin{array}{c}\text { Annealing } \\
\text { temperature } \\
\left({ }^{\circ} \mathrm{C}\right) \\
\end{array}$ & $\begin{array}{l}\text { Forward } \\
\left(5^{\prime}-3^{\prime}\right)\end{array}$ & $\begin{array}{l}\text { Reverse } \\
\left(5^{\prime}-3^{\prime}\right)\end{array}$ & $\begin{array}{l}\text { Expected } \\
\text { size (bp) }\end{array}$ \\
\hline $\begin{array}{l}\text { TRAP-transporter } \\
\text { substrate-binding protein }\end{array}$ & blr4511 & 59 & $\begin{array}{l}\text { TTTTCCCGACGCA } \\
\text { CGCTTCTCA }\end{array}$ & $\begin{array}{l}\text { AGAGCTTGCCGAC } \\
\text { GGCCTTCT }\end{array}$ & 1009 \\
\hline $\begin{array}{l}\text { Sugar ABC-transporter } \\
\text { substrate-binding protein }\end{array}$ & $\begin{array}{c}\text { blr3208 } \\
(\operatorname{chv} \mathrm{E})\end{array}$ & 58 & $\begin{array}{l}\text { TGAAGACGACAT } \\
\text { TCCTCGCGCT }\end{array}$ & $\begin{array}{l}\text { GTAGTAGCCGCTG } \\
\text { TCCACCAG }\end{array}$ & 1043 \\
\hline $\begin{array}{l}\text { ABC-transporter } \\
\text { substrate-binding protein }\end{array}$ & bll7921 & 58 & $\begin{array}{l}\text { CTCCGCAGACGTG } \\
\text { CGATCACA }\end{array}$ & $\begin{array}{c}\text { CTACTGCATCGA } \\
\text { CACCAGCGAG }\end{array}$ & 1790 \\
\hline $\begin{array}{l}\text { ABC-transporter } \\
\text { ATP-binding protein }\end{array}$ & bll5893 & 58 & $\begin{array}{c}\text { GTGACGATGGCC } \\
\text { CAGGAAACC }\end{array}$ & $\begin{array}{c}\text { TATTGCCTCAGCCA } \\
\text { GGGATGC }\end{array}$ & 752 \\
\hline
\end{tabular}

\section{PCR amplification}

For each reaction, the following was used in a final volume of $50 \mu \mathrm{L}$ : dNTPs (300 mM of each); PCR buffer $(20 \mathrm{mM}$ tris base, $\mathrm{pH} 8.4$, and $50 \mathrm{mM}$ $\mathrm{KCl}$ ), primers (20 pmol), Taq DNA polymerase (1.0 $\mathrm{U})$, and DNA template (20 ng). The amplification cycles were done as described by Ribeiro et al. (2009) with modified annealing temperature of primers, according to Table 1 . The initial denaturation cycle was at $95{ }^{\circ} \mathrm{C}$ for $2 \mathrm{~min}$, followed by 35 denaturation cycles at $94{ }^{\circ} \mathrm{C}$ for $45 \mathrm{~s}$, annealing temperature according to each primer for $45 \mathrm{~s}$, and extension at $72{ }^{\circ} \mathrm{C}$ for $5 \mathrm{~min}$. All 14 reactions were done in a Master Cycler Gradient thermocycler (Eppendorf ${ }^{\circledR}$ ). The strains without amplicons were not considered in the next assays and the genes (Table1) that were more representative in 14 strains were chosen for sequencing.
Restriction analysis (PCR-RFLP) of amplified genes

The restriction enzyme for PCR-RFLP was chosen based on in silico analysis of the gene sequences blr4511 and blr3208 (also chvE) of $B$. japonicum (USDA110) strain with the software Restriction Mapper (http://www.restrictionmapper. org/). AccI with one cutting site for blr4511 (708 and $301 \mathrm{bp}$ ) and three cutting sites for blr3208 (525, 370,102 , and $46 \mathrm{bp}$ ) was used in the analyses.

The PCR products were precipitated by adding to the reaction products 1:10 (volume: volume) $3 \mathrm{M}$ sodium acetate, three volumes of cold ethanol, and kept in ice for $5 \mathrm{~min}$. The ethanol was discarded, the precipitated DNA was re-suspended in $30 \mu \mathrm{L}$ ultrapure water, and stored at $-20{ }^{\circ} \mathrm{C}$ for posterior digestion with restriction enzymes.

After the PCR products obtained for each gene had been individually digested with several 
restriction endonucleases, the $A c c$ I enzyme was chosen to proceed with the analyzes. The digestion conditions were carried out according to the manufacturer's specifications. The RFLP products were analyzed by electrophoresis in 3\% agarose gel with ethidium bromide $\left(10 \mathrm{mg} \mathrm{mL}^{-1}\right)$ added to $0.5 \mu \mathrm{g} \mathrm{mL} \mathrm{m}^{-1}$ final concentration, and photographed under ultraviolet light.

\section{Gene sequencing}

PCR amplified products of the genes were purified using the purelink PCR purification kit (Life Technologies) according to the manufacturer's protocols, and sequenced by an ABI-prism 3100 genetic analyzer (Applied Biosystems, Foster City, CA, USA) according to the manufacturer's protocols. The nucleotide sequences were submitted to GenBank (NCBI) to obtain the access numbers.

\section{Multiple alignment}

The multiple alignment of nucleotide sequences of genes was carried out using the ClustalW program (https://www.genome.jp/tools-bin/clustalw) according to the protocol described by the program.

\section{Results and Discussion}

Among the four analyzed genes potentially related to BNF efficiency in soybean (Table 1), only blr3208 and blr4511, amplified for most of the strains (Table 2), were selected for the next assays. The bll5893 and the bll7921 genes amplified for a few strains (Table 2) and were not selected for further assays. Of the 14 strains evaluated, only 12 had their blr3208 gene and 10 had their blr4511 gene amplified by PCR (Table 2).

Table 2

PCR amplification of four genes of Bradyrhizobium spp. strains

\begin{tabular}{lcccc}
\hline \multirow{2}{*}{ Strains } & \multicolumn{5}{c}{ Genes } \\
\cline { 2 - 5 } & blr3208 & blr4511 & bll5893 & bll7921 \\
\hline CPAC7 & - & - & - & - \\
S204 & + & + & - & - \\
S340 & + & + & - & - \\
S370 & + & + & + & - \\
S372 & + & + & - & - \\
S406 & + & - & + & - \\
S452 & + & + & - & - \\
S468 & + & + & - & - \\
S478 & + & + & - & - \\
S490 & + & + & - & + \\
S516 & + & - & - & - \\
SEMIA586 & + & + & - & + \\
USDA110 & + & - & + & - \\
USDA6 & - & - & - & \\
\hline
\end{tabular}

* "+" and "-" indicates with or without amplification, respectively, for each gene in the respective strain.

Only the strains in which blr3208 and blr4511 genes were amplified were subjected to PCRRFLP analysis with the $A c c$ I endonuclease and no polymorphism was identified. Some $A c c$ I restriction profile examples of blr4511 gene (Figure 1A) and blr3208 gene (Figure 1B) are shown. 
A

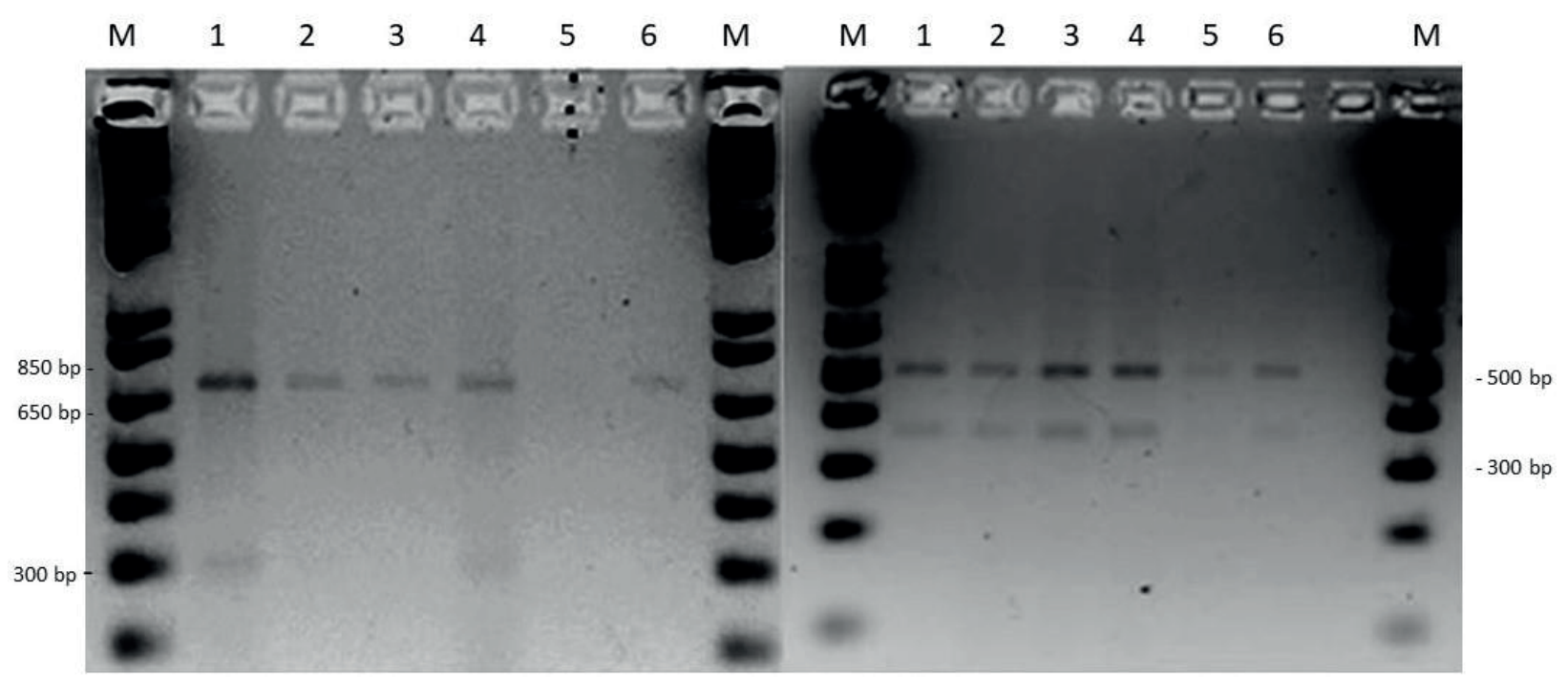

Figure 1. Restriction profiles of blr4511 (A) and blr3208 (B) genes with AccI endonuclease after electrophoresis in 3\% agarose gel. (M) Molecular mass marker (1 kb plus DNA ladder). (A) 1-6 strains: USDA110, S340, S468, S478, and S452; (B) 1-6 strains: USDA110, S516, S452, S204, S372, and S406.

Bradyrhizobium spp. strains S204, S340, sequenced and only the gene sequences with quality S370, S372, S468, S478, S516, SEMIA586, and were deposited in the GenBank (Table 3). USDA110 had the blr3208 and/or blr4511 genes

Table 3

Sequenced amplicons of blr3208 and bl4511 genes of Bradyrhizobium spp. strains with the respective GenBank access number

\begin{tabular}{lcc}
\hline & \multirow{2}{*}{ Strain } & \multicolumn{2}{c}{ GenBank access number } \\
\cline { 2 - 3 } & Slr3208 & blr4511 \\
\hline S204 & - & MH392304 \\
S340 & MH392310 & MH392305 \\
S370 & MH392311 & MH392306 \\
S372 & MH392312 & MH392307 \\
S468 & MH392313 & - \\
S478 & MH392314 & - \\
S516 & - & MH392308 \\
SEMIA586 & MH392315 & - \\
USDA110 & MH392309 & - \\
\hline
\end{tabular}

The comparison among nucleotide sequences by multiple alignment analysis (Figures 2 and 3) showed the presence of preserved internal regions of these genes, confirming the results of the restriction analysis that showed no polymorphism (Figure 1A and 1B). 
S.372-Sugar S. 478-Sugar USDA110-Sugar

S.340-Sugar

S.370-Sugar

SEMIA. 586-Sugar

S.468-Sugar

S.372-Sugar

S.478-Sugar

USDA110-Sugar

S.340-Sugar

s.370-Sugar

SEMIA. 586-Sugar

s.468-Sugar

s.372-Sugar

s. 478-Sugar

USDA110-Sugar

S.340-Sugar

s.370-Sugar

SEMIA. 586-Sugar

S. 468-Sugar

s.372-Sugar

S.478-Sugar

USDA110-Sugar

8.340-Sugar

s.370-Sugar

SEMIA. 586-Sugar

S.468-Sugar

S.372-Sugar

S.478-Sugar

USDA110-Sugar

S.340-Sugar

s.370-Sugar

SEMIA. 586-Sugar

s. 468-Sugar

s.372-sugar

S. 478-Sugar

USDA110-Sugar

S.340-Sugar

s.370-Sugar

SEMIA. 586-Sugar

S.468-Sugar

s.372-Sugar

S.478-Sugar

USDA110-Sugar

S. 340-Sugar

s.370-Sugar

SEMIA. 586-Sugar

S.468-Sugar

s.372-Sugar

S.478-Sugar

USDA110-Sugar

S. 340-Sugar

s.370-sugar

SEMIA. 586-Sugar

S.468-Sugar

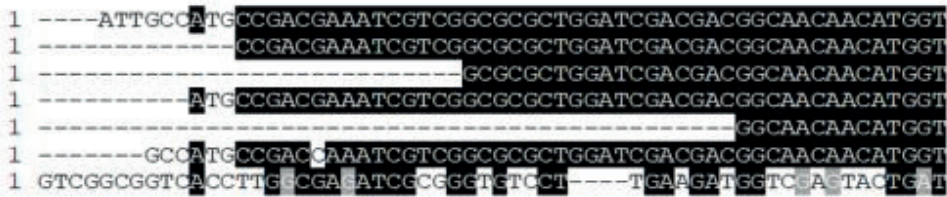

$57 \mathrm{C}$

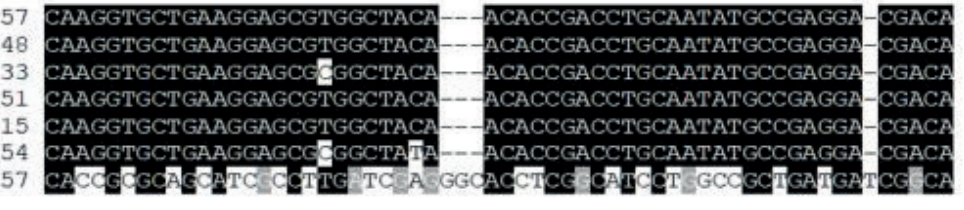

13 TCCCGAACCAGCTCTCGCAGGTCGAGAACATGGTGACCAAGGGTGCGAAAGCGCTGGTG

104 TCCCGAACCAGCTCTCGCAGGTCGAGAACATGGTGACCAAGGGTGCGAAAGCGCTGGTGF

89 TCCCGAACCAGCTCTCGCAGGTCGAGAACATGGTGACCAAGGGCGCGAA GCGCTGGTG

107 TCCCGAACCAGCTCTCGCAGGTCGAGAACATGGTGACCAAGGGTGCGAAAGCGCTGGTGA

71 TCCCGAACCAGCTCTCGCAGGTCGAGAACATGGTGACCAAGGGTGCGAAAGCGCTGGTGP

110 TCCCGAACCAGCTCTCGCAGGTCGAGACATGGT GACCAAGGGCGCGA GCGCTGGTGA

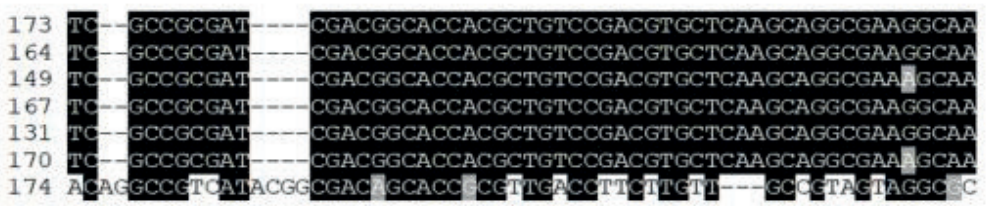

227 AAGGCATCACCGTGATCGCCTATGACCGCCTCATCCGCGGCACGCCGAACGTCGACTAT

218 AAGGCATCACCGTGATCGCCTATGACCGCCTCATCCGCGGCACGCCGAACGTCGACTAT"

203 AAGGCATCACGTGAT GCCTATGACCGCCT GATCCGCGGCACGCCGAACGTCGACTAT"

221 AAGGCATCACCGTGATCGCCTATGACCGCCTCATCCGCGGCACGCCGAACGTCGACTATT

185 AAGGCATCACCGT GATCGCCTATGACCGCCTCATCCGCGGCACGCCGAACGTCGACTAT'T

224 AAGGCATCACGTGATIGCCTATGACCGCCTGATCCGCGGCACGCCGAACGTCGACTACH

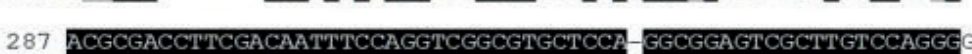

287 ACGCGACCTTCGACANTTCCAGGTCGGCGTGCTCCA-GGCGGAGTCGCTTGTCCAGGG
278 ACGCGACCTTCGACAATTCCAGGTCGGCGTGCTCCA-GGCGGAGTCGCTTGT---

263 ACGCGACCTTCGACAATTTCCAGGTCGGCFTGCTCCA-EGCGGAGTCE--

281 ACGCGACCTTCGACAATTTCCAGGTCGGCGTGCTCCA-GGCGGAGTCGCTTGTCCAGGG

245 ACGCGACCTTCGACAATTTCCAGGTCGGCGTGCTCCA-GGCGGAGTCGCTTGTCCAGGGG

284 ACGCGACCTTCGACAATTTCCAGGTCGGCGTGCTCCA-GGCGGAGTCGCICGI CCAGGGT

346 CTCGGCCT AAGGACGGCAAGGGCCGTTCAACATCGAGCT TTCGGCGGCTCGCCCGA
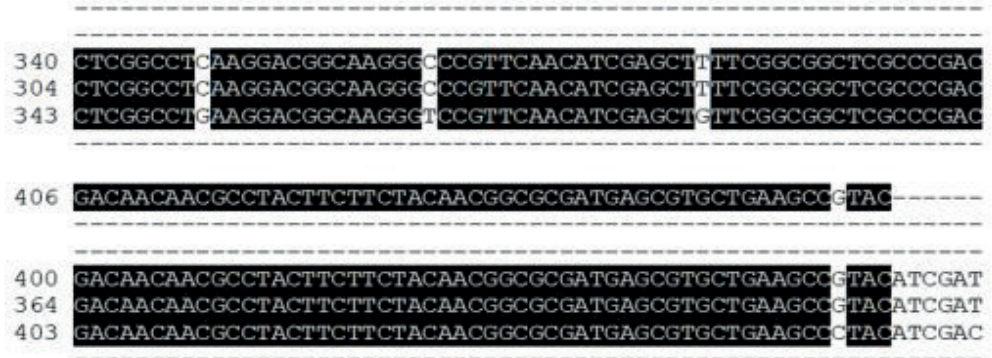

Figure 2. Sequence of multiple alignment of blr3208 gene (sugar transporter) performed with ClustalW software (https://www.genome.jp/tools-bin/clustalw) for S340, S370, S372, S468, S478, SEMIA586, and USDA110 strains. 


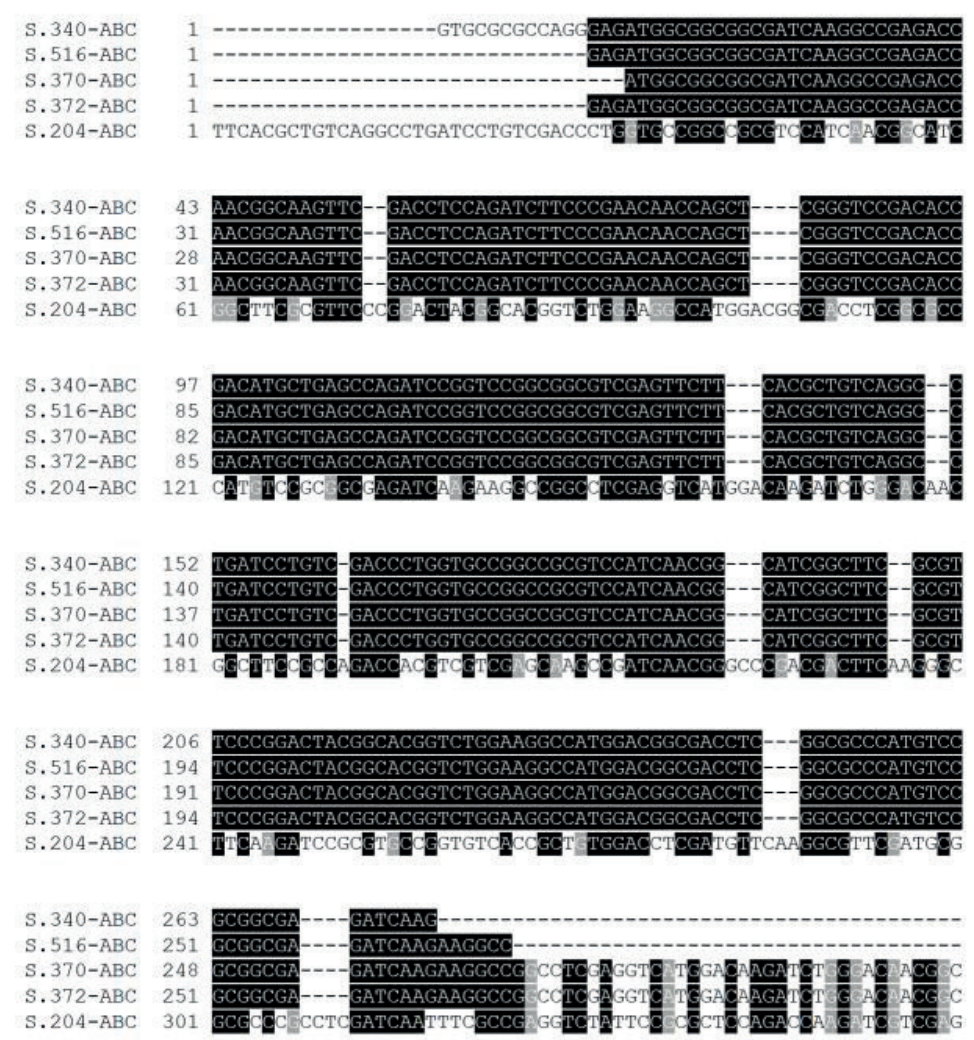

Figure 3. Sequence of multiple alignment of blr4511 gene (TRAP transporter) performed with ClustalW program (https://www. genome.jp/tools-bin/clustalw) for S204, S340, S370, S372, and S516 strains.

The comparison of the sequence of blr3208 gene from USDA110 with sequences of strains deposited in the GenBank database (NCBI) with BLAST program (http://blast.ncbi.nlm.nih.gov) is shown in Table 4. Similarity over $90 \%$ among sequences of different species and strains of the genus Bradyrhizobium (Table 4) was observed. Based on the similarity analysis of the blr4511 gene with sequences deposited in the GenBank database (NCBI), a similarity over $85 \%$ was found with gene sequences of the genus Bradyrhizobium (Table 5), known as DctP, which coded a group of proteins named transporter substrate-binding protein (TRAP), more specifically "TRAP-type C4-dicarboxylate transport system, periplasmic component" that transport C4-dicarboxylate acid, as succinate. 
Table 4

Similarity among nucleotide sequences of blr3208 gene from Bradyrhizobium japonicum strain USDA110 (also Bradyrhizobium diazoefficiens) and sequences of strains deposited in the Genbank database, using the BLAST (NCBI) software with the ten most similar results

\begin{tabular}{lccc}
\hline Strain & Query cover (\%) & E-value & Identity (\%) \\
\hline Bradyrhizobium diazoefficiens strain XF7 & 100 & 0.0 & 100 \\
Bradyrhizobium diazoefficiens strain USDA 122 & 100 & 0.0 & 99.4 \\
Bradyrhizobium diazoefficiens strain NK6 & 99 & 0.0 & 99.4 \\
Bradyrhizobium sp. strain G22 & 100 & 0.0 & 95.2 \\
Bradyrhizobium japonicum strain E109 & 100 & 0.0 & 95.2 \\
Bradyrhizobium japonicum strain USDA 6 & 100 & 0.0 & 95.2 \\
Bradyrhizobium japonicum strain J5 & 100 & 0.0 & 95.1 \\
Bradyrhizobium japonicum strain SEMIA 5079 & 100 & 0.0 & 94.7 \\
Bradyrhizobium sp. strain BF49 & 100 & 0.0 & 94.6 \\
Bradyrhizobium ottawaense strain OO99 & 99 & 0.0 & 94.5 \\
\hline
\end{tabular}

Table 5

Similarity among nucleotide sequences of blr4511 gene from Bradyrhizobium japonicum strain USDA110 (also Bradyrhizobium diazoefficiens) and strains deposited in the Genbank database, using the BLAST (NCBI) program with the first ten results obtained

\begin{tabular}{lccc}
\hline Strain & Query cover (\%) & E-value & Identity (\%) \\
\hline Bradyrhizobium diazoefficiens strain XF7 & 100 & 0.0 & 99.90 \\
Bradyrhizobium diazoefficiens strain USDA 122 & 100 & 0.0 & 99.80 \\
Bradyrhizobium diazoefficiens strain NK6 & 94 & 0.0 & 98.45 \\
Bradyrhizobium sp. strain G22 & 100 & 0.0 & 94.80 \\
Bradyrhizobium sp. strain CCBAU 51778 & 100 & 0.0 & 94.41 \\
Bradyrhizobium japonicum strain SEMIA 5079 & 100 & 0.0 & 94.41 \\
Bradyrhizobium japonicum strain J5 & 100 & 0.0 & 94.31 \\
Bradyrhizobium sp. strain ORS 3257 & 100 & 0.0 & 94.39 \\
Bradyrhizobium japonicum strain E109 & 100 & 0.0 & 94.22 \\
Bradyrhizobium japonicum strain USDA 6 & 100 & 0.0 & 94.22 \\
\hline
\end{tabular}

Originally identified in the genome (chromosome DNA) of Rhizobium (Agrobacterium) tumefaciens (Smith and Townsend) Conn (Kemner, Liang, \& Nester, 1997), renamed to Rhizobium radiobacter (Beijerinck and van Delden) (Young, Kuykendall, Martínez-Romero, Kerr, \& Sawada, 2001), the blr3208 gene encodes a binding protein (ChvE protein) which is part of the $\mathrm{ABC}$-type protein complex, responsible for detection of sugars (monosaccharides) released by plant roots (Kemner et al., 1997; Brencic \& Winans, 2005; Eitinger, Rodionov, Grote, \& Schneider, 2011). The ChvE protein, chromosomally encoded is located in the periplasmic space and participates in chemotaxis and virulence gene induction in response to monosaccharides occurring in the plant wound environment (Kemner et al., 1997; Hu, Zhao, DeGrado, \& Binns, 2013; Nester, 2015). This ABCtype protein complex participates in the bacterial chemotaxis process and interacts with a membrane protein, VirA, activating the virulence process of the bacteria (Kemner et al., 1997; Guo, Huang, \& Yang, 2017).

The sequence comparison analysis of blr3208 gene from USDA110 with sequences deposited at the GenBank database (NCBI) found a great 
level of similarity with different sequences of Bradyrhizobium spp. and other genera. The high level of similarity found for blr3208 gene among the different rhizobial strains showed a high level of gene conservation that can be due to a possible adaptive function of ChvE protein in the infection and/or symbiosis process of rhizobia with host plants during the evolution process.

The presence of highly-conserved internal regions and the absence of polymorphism in genes related to BNF efficiency, as nopP and aapP genes, suggest their potential functions in plant-microbe interactions, as previously reported by Perin et al. (2018) for the same B. japonicum strains assessed in this study. The nopP gene codifies a secretion protein related to the infection process, the nodulation outer protein $\mathrm{P}$, and the aapP gene codifies one of the proteins that compose an amino acid transport system located in the plasmatic membrane. The authors also related the high conservation of these genes to adaptive functions.

Similar to observed for the blr3208 gene, the sequence comparison analysis of blr4511 gene of USDA110 strain with sequences deposited in the GenBank database showed a high similarity of gene sequences with other rhizobia. Originally identified in USDA110 strain, the blr4511 gene was characterized as a hypothetical gene in the functional category of "transport and binding proteins", and coded as a protein of "ABC-transporter substratebinding” group (https://www.genome.jp/dbget-bin/ www_bget?bja:blr4511). Similarity could also be observed with gene sequences known as DetP of Bradyrhizobium spp., which coded a group of proteins named TRAP, more specifically "TRAPtype $\mathrm{C} 4$-dicarboxylate transport system, periplasmic component". These transporters carry C4dicarboxylate acid, as succinate, helping the BNF process (Yurgel \& Kahn, 2004; Geddes \& Oresnik, 2016). Therefore, the similarity identified for the blr4511 gene among rhizobia may be due to the conservation during the evolution of this function by the transporter protein encoded by this gene. Just like observed for the blr3208 gene, the evolutionary conservation of blr4511 gene explains the difficulty to identify polymorphisms. The non-identification of polymorphisms of blr3208 and blr4511 genes by PCR-RFLP technique and sequence alignment analysis among the studied strains is probably due to the high level of preservation of these genes in Bradyrhizobium spp.

\section{Conclusion}

The characterization of genes involved in soybean BNF helps to understand this process. From the four genes related to BNF such as blr4511, bll7921, bll5893, and blr3208, characterized in contrasting B. japonicum strains regarding BNF efficiency, only blr3208 and blr4511 genes amplified for most of the strains. The blr3208 and blr4511 genes involved in soybean BNF showed to be highly conserved among $B$. japonicum strains and the conservation of these genes may be related to the adaptive function during the evolutionary process.

\section{Acknowledgments}

The authors thank Universidade Paranaense, Universidade Estadual de Londrina, Fundação Araucária, Coordenação de Aperfeiçoamento de Pessoal de Nível Superior - Brazil (CAPES) -finance code 001-, and Conselho Nacional de Desenvolvimento Científico e Tecnológico (CNPq) for the financial support and fellowship.

\section{References}

Barcellos, F. G., Batista, J. S. S., Menna, P., \& Hungria, M. (2009). Genetic differences between Bradyrhizobium japonicum variant strains contrasting $\mathrm{N}_{2}$-fixation efficiency revealed by representational difference analysis. Archives of Microbiology, 191(2), 113-122. doi: 10.1007/s00203-008-0432-0

Batista, J. S. S., \& Hungria, M. (2012). Proteomics reveals differential expression of proteins related to a variety of metabolic pathways by genisteininduced Bradyrhizobium japonicum strains. Journal 
of Proteomics, 75(4), 1211-1219. doi: 10.1016/j. jprot.2011.10.032

Bortolan, S., Barcellos, F. G., Marcelino, F. C., \& Hungria, M. (2009). Expressão dos genes nod $C, \operatorname{nod} W e$ nopP em Bradyrhizobium japonicum estirpe CPAC 15 avaliada por RT-qPCR. Pesquisa Agropecuária Brasileira, 44(11), 1491-1498. doi: 10.1590/S0100204X2009001100017

Brencic, A., \& Winans, S. C. (2005). Detection of and response to signals involved in hostmicrobe interactions by plant-associated bacteria. Microbiology and Molecular Biology Review, 69(1), 155-194. doi: 10.1128/MMBR.69.1.155-194.2005

Caetano-Anollés, G., \& Gresshoff, P. M. (1991). Plant genetic control of nodulation. Annual Review of Microbiology, 45, 345-382. doi: 10.1146/annurev. mi.45.100191.002021

Delamuta, J. R. M., Ribeiro, R. A., Ormeño-Orrillo, E., Melo, I. S., Martínez-Romero, E., \& Hungria, M., (2013). Polyphasic evidence supporting the reclassification of Bradyrhizobium japonicum group Ia strains as Bradyrhizobium diazoefficiens sp. nov. International Journal of Systematic and Evolutionary Microbiology, 63(9), 3342-3351. doi: 10.1099/ijs.0.049130-0

Eitinger, T., Rodionov, D. A., Grote, M., \& Schneider, E. (2011). Canonical and ECF-type ATP-binding cassette importers in prokaryotes: diversity in modular organization and cellular functions. FEMS Microbiology Reviews, 35(1), 3-67. doi: 10.1111/j.1574-6976.2010.00230.x

Geddes, B. A., \& Oresnik, I. J. (2016). The mechanism of symbiotic nitrogen fixation. In: Hurst C. (ed), The mechanistic benefits of microbial symbionts advances in environmental microbiology 2 (pp. 6997). Cham, CH: Springer International Publishing. doi: 10.1007/978-3-319-28068-4_4

Godoy, L. P., Vasconcelos, A. T. R., Chueire, L. M. O., Souza, R. C., Nicolás, M. F., Barcellos, F. G., \& Hungria, M. (2008). Genomic panorama of Bradyrhizobium japonicum CPAC 15, a commercial inoculant strain largely established in Brazilian soils and belonging to the same serogroup as USDA 123 . Soil Biology and Biochemistry, 40(11), 2743-2753. doi: 10.1016/j.soilbio.2008.07.016

Göttfert, M. (1993). Regulation and function of rhizobial nodulation genes. FEMS Microbiology Reviews, 104(1-2), 39-64. doi: 10.1111/j.1574-6968.1993. tb05863
Guo, M., Huang, Z., \& Yang, J. (2017). Is there any crosstalk between the chemotaxis and virulence induction signaling in Agrobacterium tumefaciens? Biotechnology Advances, 35(4), 505-511. doi: 10. 1016/j.biotechadv.2017.03.008

Hu, X., Zhao, J., DeGrado, W. F., \& Binns, A. N. (2013). Agrobacterium tumefaciens recognizes its host plant environment using ChvE to bind diverse plant sugars as virulence signals. Proceedings of the National Academy of Sciences of the United States of America, 110(2), 678-683. doi: 10.1073/pnas.1215033110

Hungria, M., \& Mendes, I. C. (2015). Nitrogen fixation with soybean: the perfect symbiosis? In F. J. de Bruijn (Ed.), Biological nitrogen fixation (pp. 1009-1024). New Jersey: John Wiley \& Sons, Inc. Retrieved from http://dx.doi.org/10.1002/9781119053095.ch99

Hungria, M., \& Stacey, G. (1997). Molecular signals exchanged between host plants and rhizobia: basic aspects and potential application in agriculture. Soil Biology and Biochemistry, 29(1-2), 819-830. doi: 10.1016/S0038-0717(96)00239-8

Hungria, M., Boddey, L. H., Santos, M. A., \& Vargas, M. A. T. (1998). Nitrogen fixation capacity and nodule occupancy by Bradyrhizobium japonicum and $B$. elkanii strains. Biology and Fertility of Soils, 27(4), 393-399. doi: 10.1007/s003740050449

Hungria, M., Campo, R. J., \& Mendes, I. C. (2007). A importância do processo de fixação biológica do nitrogênio para a cultura da soja: componente essencial para a competitividade do produto brasileiro. Londrina, PR: EMBRAPA Soja.

Jordan, D. C. (1982). Transfer of Rhizobium japonicum Buchanan 1980 to Bradyrhizobium gen. nov., a genus of slow-growing, root nodule bacteria from leguminous plants. International Journal of Systematic Bacteriology, 32(1), 136-139. doi: 10.1099/00207713-32-1-136

Kalendar, R., Lee, D., \& Schulman, A. H. (2009). Fast PCR software for PCR primer and probe design and repeat search. Genes, Genomes and Genomics, 3(1), 1-14. Retrieved from http://www.globalscience books.info/Online/GSBOnline/images/0906/ GGG_3(SI1)/GGG_3(SI1)1-140.pdf

Kaminski, P. A., Batut, J., \& Boistard, P. (1998). A survey of symbiotic nitrogen fixation by rhizobia. In $\mathrm{H}$. P. Spaink, A. Kondorosi, P. J. J. Hooykaas (eds) The Rhizobiaceae (pp. 431-460). The Netherlands: Springer, Dordrecht. doi: 10.1007/978-94-0115060-6_23 
Kaneko, T., Nakamura, Y., Sato, S., Minamisawa, K., Uchiumi, T., Sasamoto, S.,... Tabata, S. (2002). Complete genomic sequence of nitrogen-fixing symbiotic bacterium Bradyrhizobium japonicum USDA 110. DNA Research, 9(6), 189-197. doi: 10.1093/dnares/9.6.189

Kemner, J. M., Liang, X., \& Nester, E. W. (1997). The Agrobacterium tumefaciens virulence gene chvE is part of a putative ABC-type sugar transport operon. Journal of Bacteriology, 179(7), 2452-2458. doi: 10.1128/jb.179.7.2452-2458.1997

Kijne, J. W. (1992). The Rhizobium infection process. In G. Stacey, R.H. Burris, \& H. J. Evans (Eds.), Biological nitrogen fixation (pp. 349-398). New York, NY: Chapman \& Hall.

Lisitsyn, N., Lisitsyn, N., \& Wigler, M. (1993). Cloning the differences between two complex genomes. Science, 259(5097), 946-951. doi: 10.1126/ science. 8438152

Liu, C. W., \& Murray, J. D. (2016). The role of flavonoids in nodulation host-range specificity: an update. Plants, 5(3), 33. doi: 10.3390/plants5030033

Mahmud, K., Makaju, S., Ibrahim, R., \& Missaoui, A. (2020). Current progress in nitrogen fixing plants and microbiome research. Plants, 9(1), 97. doi: 10.3390/ plants9010097

Nester, E. W. (2015) Agrobacterium: nature's genetic engineer. Frontiers in Plant Science, 5, 730. doi: 10.3389/fpls.2014.00730

Orrell, T., \& Nicolson, D. (2020). ITIS: The integrated taxonomic information system. In Y. Roskov, G. Ower, T. Orrell, D. Nicolson, N. Bailly, P. M. Kirk, T. Bourgoin; R. E. DeWalt, W. Decock, E. van Nieukerken, \& L. Penev (Eds.), Species 2000 \& ITIS catalogue of life, 2020-08-01 Beta Naturalis, Leiden, The Netherlands. Recovered from www. catalogueoflife.org/col.Species 2000

Passaglia, L. M. P. (2017). Bradyrhizobium elkanii nod regulon: insights through genomic analysis. Genetics and Molecular Biology, 40(3), 703-716. doi: 10.1590/1678-4685-gmb-2016-0228

Perin, J. G., Bertéli, M. B. D., Valle, J. S. do, Linde, G. A., Paccola-Meirelles, L. D., Colauto, N. B., \& Barcellos, F. G. (2018). Characterization of aapP and nopP genes related to the biological nitrogen fixation efficiency with soybean in contrasting strains of Bradyrhizobium japonicum. Genetics Molecular Research 17(1), gmr16039867. doi: 10.4238/gmr16039867
Reis, F. B. dos, Jr., Mendes, I. C., Reis, V. M., \& Hungria, M. (2011). Fixação biológica de nitrogênio uma revolução na agricultura. In F. G. Faleiro, S. R. M. de Andrade, \& F. B. dos Reis Jr. (Eds.), Biotecnologia: estado da arte e aplicações na agropecuária (pp. 247-281). Planaltina, DF: EMBRAPA Cerrado.

Ribeiro, R. A., Barcellos, F. G., Thompson, F. L., \& Hungria, M. (2009). Multilocus sequence analysis of Brazilian Rhizobium microsymbionts of common beans (Phaseolus vulgaris L.) reveals unexpected taxonomic diversity. Research in Microbiology, 160(4), 297-306. doi: 10.1016/j.resmic.2009.03.009

Santos, M. A., Nicolás, M. F., \& Hungria, M. (2006). Identificação de QTL associados à simbiose entre Bradyrhizobium japonicum, B. elkanii e soja. Pesquisa Agropecuária Brasileira, 41(1), 67-75. doi: 10. 1590/S0100-204X2006000100010

Santos, M. A., Vargas, M. A. T., \& Hungria, M. (1999). Characterization of soybean Bradyrhizobium strains adapted to the Brazilian savannas. FEMS Microbiology Ecology, 30(3), 261-272. doi: 10.1111/ j.1574-6941.1999.tb00654.x

Shamseldin, A. (2013). The role of different genes involved in symbiotic nitrogen fixation - review. Global Journal of Biotechnology \& Biochemistry, 8(4), 84-94. doi: 10.5829/idosi.gjbb.2013.8.4.82103

Sharma, V., Bhattacharyya, S., Kumar, R., Kumar, A., Ibañez, F., Wang, J.,... Pandey, M. K. (2020). Molecular basis of root nodule symbiosis between Bradyrhizobium and 'crack-entry' legume groundnut (Arachis hypogaea L.). Plants, 9(2), 276. doi: $10.3390 /$ plants 9020276

Silva, A. F., Freitas, A. D. S. de, \& Stamford, N. P. (2002). Efeito da inoculação da soja (cv. Tropical) com rizóbios de crescimento rápido e lento em solo ácido submetido à calagem. Acta Scientiarum Agronomy, 24(5), 1327-1333. doi: 10.4025/actasciagron. v24i0.2371

Spaink, H. P. (2000). Root nodulation and infection factors produced by rhizobial bacteria. Annual Review of Microbiology, 54, 257-288. doi: 10.1146/ annurev.micro.54.1.257

Van Hameren, B., Hayashi, S., Gresshoff, P. M., \& Ferguson, B. J. (2013). Advances in the identification of novel factors required in soybean nodulation, a process critical to sustainable agriculture and food security. Journal of Plant Biology \& Soil Health, 1(1), 6 .

Vincent, J. M. (1970). A manual for the practical study of the root-nodule bacteria. Oxford: Blackwell Scientific Publications. 
Wang, Q., Liu, J., \& Zhu, H. (2018). Genetic and molecular mechanisms underlying symbiotic specificity in legume Rhizobium interactions. Frontiers in Plant Science, 9, 313. doi: 10.3389/fpls.2018.00313

Wei, M., Yokoyama, T., Minamisava, K., Mitsui, H., Itakura, M., Kaneko, T.,... Ohwada, T. (2008). Soybean seed extracts preferentially express genomic loci of Bradyrhizobium japonicum in the initial interaction with soybean, Glycine $\max (\mathrm{L}$.). DNA Research, 15(4), 201-214. doi: 10.1093/dnares/ dsn012
Young, J. M., Kuykendall, L. D., Martínez-Romero, E., Kerr, A., \& Sawada, H. (2001). A revision of Rhizobium Frank 1889, with an emended description of the genus, and the inclusion of all species of Agrobacterium Conn 1942 and Allorhizobium undicola de Lajudie et al. 1998 as new combinations: Rhizobium radiobacter, $R$. rhizogenes, R. rubi, $R$. nicola and $R$. vitis. International Journal of Systematic and Evolutionary Microbiology, 51(1), 89-103. doi: 10.1099/00207713-51-1-89

Yurgel, S. N., \& Kahn, M. L. (2004). Dicarboxylate transport by rhizobia. FEMS Microbiology Reviews, 28(4), 489-501. doi: 10.1016/j.femsre.2004.04.002 
